\title{
Social housing under the Workers' Party government: an analysis of the private sector in Brazil
}

\author{
Valesca Lima \\ School of Politics and International Relations, University College Dublin, Dublin, Ireland
}

\begin{abstract}
This article examines the patterns of government intervention in social housing in Brazil to analyse the role of the private sector in the elaboration and implementation of social housing policies during the Workers' Party government. It draws on case study research, and I examine areas which impact on the way social housing has been implemented since 2003 to study the concentration of decision power the private construction sector has on social housing policymaking, which sets the tone of government intervention on social housing. I argue this was part of the Workers' Party's approach to neoliberal policies in a more moderated style, a type of intervention repeated on numerous occasions under previous administrations. This article concludes by noting the prominent role of the private sector in social housing developments.
\end{abstract}

\section{ARTICLE HISTORY}

Received 28 May 2017

Accepted 20 November 2017

\section{KEYWORDS}

Housing

private sector

neoliberalism

social movements

Brazil

\section{Introduction}

An impressive number of academics have dedicated their work to analysing the housing issue in Brazil. ${ }^{1}$ Generally, there is an undisputed view that the state has been unable to deal satisfactorily with the housing problem. Since the creation of the first large housing programmes in the 1950s and 1960s, governments have demonstrated an inability to attend to the housing needs of the low-income population, ${ }^{2}$ which is the group where the housing deficit is primarily concentrated. ${ }^{3}$

My analysis in this paper presents the main actors and strategies playing a key role in social housing policymaking in Brazil during Workers' Party governments. I begin with the assumption that the housing issue in Brazil returned to the centre of the government's political agenda in 2003 with the election of a Workers' Party candidate, Lula. His administration initiated a process of change in the housing area, such as the creation of the Ministry of Cities and new regulations for the housing sector, in addition to programmes with comprehensive scope and national reach. It is noteworthy to mention in this context the creation of the National Housing System in 2005, a system in which municipalities became members to receive federal funds and technical support. In exchange, municipalities had to implement 
the 'architecture of participation', which included the participation of civil society and the private sector in the process of public policy decision-making. ${ }^{4}$

The My Home, My Life social housing programme (Programa Minha Casa, Minha Vida PMCMV) is one of the biggest housing intervention programmes implemented nationwide. Created in 2009, the PMCMV was devised to address issues associated with the housing deficit and to attend to the estimated future housing demand of Brazil until 2023. The PMCMV's main goal is the eradication of precarious housing and cohabitation by providing low-income families with decent housing.

The PMCMV surged as a response to the 2008 economic crisis, which by early 2009 rose to concerning levels in Latin America and Brazil as the international crises impacted the national market. ${ }^{5}$ The objective of the programme was to stimulate the growth of economic activity. An important part of these incentives was concentrated on the infrastructure and construction sector, because the sector has an important role in generating employment and is considered a 'strategic partner' of the government. The magnitude of this Brazilian programme has pleased the construction sector. In 2016, the Federal Government reserved 70 billion reais ( $€ 19$ billion) from the budget to be directed to the PMCMV programme.

At the local level, municipal housing councils decide how funding for social housing is going to be spent through the PMCMV programme. Members of local housing councils which include government officials, non-governmental organisations (NGOs), social movements and representatives of the private sector - must reach consensus on housing priorities. Previous studies have demonstrated how these councils are expected to be self-directed and equalitarian, but local politics leads to serious power imbalance that undermines the influence and participation of civil society in the process of decision-making. This power imbalance is skewed towards government and the private sector, which centralise and define the configuration of the housing investments in the country. ${ }^{6}$

Previous research has established the reformist tendencies of the Workers' Party, arguing in favour of social justice. Critics of the Workers' Party, such as Stedile and colleagues, ${ }^{7}$ suggest that Lula's administration was not exactly leftist or neoliberal, but rather something in between, representing a new political position in terms of the Brazilian political parties' history. However, analysis of Workers' Party administrations from Lula's two terms (eight years) in office (2003-2011) to Rousseff's administration (2011-2016) have been comprehensively studied in terms of their liberal neoliberal inclination. ${ }^{8}$ There is a consensus among those authors that particularly in the early stages of Lula's presidential term, there was strong evidence of alliances between the Workers' Party and capitalist interests.

Having briefly presented the housing policy scenario and its main actors, I can therefore present the three main components of analysis I use in this paper: (1) the spaces of participatory democracy - in this case, the municipal councils, which are spaces of public policy decision-making; (2) the patterns of state intervention under Workers' Party government policies; and (3) the influence and intervention of the private sector social housing decision-making processes. Thus, this paper deals with the following question: What is the extent of the private sector's influence on social housing decision-making in Brazil? I focus on the extent to which this key actor in housing councils in a participatory democracy model is associated with the setting up and pathways of social housing. This paper contributes to current discussions about new facets of neoliberalism, public policy and political crisis in Latin America. 
The case study, which provides evidence in the paper, is an empirically grounded study into the interaction between social movements' representatives and the private sector in Brazil. It is based on fieldwork conducted in 2014 and 2015 in the city of Maracanaú, a medium-sized urban municipality in the Northeast of Brazil, which included archival work, and interviews with state officials, social movements' members, and representatives of the private sector in the municipal housing council. The case study of a housing council in the municipality of Maracanaú illustrates the contradictions of combining a redistributive and social equity agenda with a neoliberal model of productivity. The analysis reveals a complex structure of power plays and the challenges for social movements under progressive governments.

\section{State intervention in housing issues: poor solutions for poor people}

In Brazil, most of the interventions in urban centres that aim to address housing issues have a segregationist pattern. The expansion of the population and a long list of failed and localised public housing policies have consequences for the current housing deficit in the country. Since the 1930s, Brazil has adopted a national developmental model that started during President Vargas' term (1930-1945) and was strengthened during the military regime (19641985). This development policy was configured by the economic expansion of cities and the development of national industries, along with the boom in occupation of urban centres. ${ }^{9}$ During this period, new cities emerged and living standards were extremely low, especially for low-income families. ${ }^{10}$ Even today, the suburbs are frequently the only place available for low-income groups, far away from their jobs and lacking essential public services, such as public schools and adequate transportation.

Looking back at the origins of the state intervention on housing issue, it is established that the period 1930-1954 (President Vargas' first term in office) shaped housing solutions for many years to come. ${ }^{11}$ This is the moment when the Brazilian state started to intervene in housing production, until then led by the private sector. ${ }^{12}$ The state production of housing for low-income groups was an acknowledgment that the housing issue would not be addressed only through private investment. Because of its nationalistic features, the Vargas government stimulated the intervention of the state in the housing area. In fact, the construction industry did not contest this meddling by the government. Large companies from the construction sector were gradually discontinuing investments in the production of 'rental houses', a sector of intense activity during the period. On the other hand, the progressive reduction of private investment in the housing industry created the perfect conditions for the injection of public resources into the construction sector - a situation that remains today. From this is possible to infer that the development of social housing required the intervention of the state in a sector of economic activity where the presence of the state was indispensable, and that it attended the interests of the construction sector. ${ }^{13}$

Few and sparse social housing programmes were created after the Vargas period. Even after the creation of the National Housing Bank (Banco Nacional de Habitação) in 1964, which was supposed to assist low-income families with social housing, most of the resources were directed to middle- and upper-class families acquiring new homes. This entity was created with the purpose of improving the economy by investing in the building sector and in social housing estates. However, it ended up as an extremely centralised policy within the federal government. After 22 years of existence - marked by reports of corruption and misuse of 
public resources - the National Housing Bank was closed in 1986. This housing system left a significant legacy of social housing policy models for years, particularly regarding state financing of home ownership. ${ }^{14}$

After the closure of the National Housing Bank, Brazilian housing policies collapsed, as an economic crisis plagued the country in the 1980s - a period of debt crisis and reverse capital flows from Latin America to the creditor countries, which prevented the execution of any major social housing policies. The focus then changed to local communities and neighbourhood associations, which received training and technical information from state officials on 'self-construction' housing. Local associations received a boost and the number of local groups working on social housing networks increased considerably. A number of entities received funding and supervision from government agencies - and in some cases from international NGOs, depending on who was financing the housing project.

The administration of the complex and decentralised housing system, in which the majority of building construction services are contracted out to the private sector, unavoidably creates conflict and contradictions. Central to the philosophy of neoliberal market approaches is the idea that government should move the provision of services to the private sector. Since the 1980s, countries in Latin America have implemented neoliberal reforms under supervision of the International Monetary Fund (IMF). These policies were implemented to promote greater efficiency and development, and also to lead to economic growth. Adjustment programmes were heavily implemented in the 1990s and steered a significant debate on programmes of economic development and fiscal stabilisation. This was a contentious debate that involved politicians aligning themselves with a neoliberal agenda, or supporting a strong role for the state as service provider. ${ }^{15}$

In this context, the logic is that the state has to intervene in the housing area to reduce economic imbalance and stimulate economic growth by investing in the construction sector. Therefore, the role of the state is to assist housing markets with land, credit and subsidies, meaning that this role is transformed by reducing its direct production of units, land policy and the determination and coordination of investments. Another important change is the modification of financing institutions to expedite private sector-led projects to foster the financial housing market. The bottom line is that the construction sector is fundamental to economic growth and urban development, as the government created the legal basis for a permanent availability of financial capital for the private sector. The funding came from national savings, loan housing systems and loans from abroad. ${ }^{16}$

In 1994, with the election of Cardoso as president, investments in social housing at the national scale resumed, with policies focused on low-income groups and facilitation of credit, such as the Pro-moradia programme and the Residential Leasing Programme (Programa de Arrendamento Residencial - PAR), which were offered to families earning onethree and three-six times the minimal wage, respectively. PAR adopted a distributive format in which construction companies presented projects to Caixa Economica Federal, the national bank responsible for operationalising the programme. Municipalities were the local agents responsible for facilitating this process by relaxing urbanistic legislation, and offering tax incentives to companies and carrying out infrastructure works to lessen the final cost of the projects, such as installing a public sanitation system. ${ }^{17}$ The PAR was applied consistently from 1994 to 2002. Only in the 2000s did social housing policies become an important government policy again, with the creation of the Ministry of Cities, the federal government department responsible for social housing policies. It was created with the objective of 
strengthening popular participation and providing access to urban equipment. In 2005, the National Housing Council and the National Social Housing Fund were also created. At the local level, all municipalities interested in obtaining funding for social housing had to apply for membership to the national housing system. The creation of a municipal housing council to manage and establish guidelines and criteria for the allocation of resources is mandatory for all members of the system. No local housing council means no federal funding for social housing.

\subsection{Participation in social housing and the My House, My Life programme}

As determined in the 1988 Constitution, federal law regulates urban spaces. The first regulation worth mentioning is the City Statute (Estatuto das Cidades) Law 10.257, passed in 2001. This law builds a new legal-urban directive to regulate policies of urban development and access to land in urban centres. It is premised on the idea of the social function of land and democratic city management. Another important instrument for the regulation of the urban space is Law 11.888, the Free Technical Assistance Programme (Programa de Assitência Técnica Gratuita) from 2008, which provides low-income families with free technical assistance for housing design and construction. This is a permanent service offered by states and municipalities. While it has been successfully implemented in some municipalities, the proper implementation of the programme faces challenges due lack of legal mechanisms and land regulation that allow for the application of this regulation.

As a rule, municipalities coordinate social housing programmes through partnership programmes funded by federal resources. The new legislation that made local housing councils mandatory had the expected effect. After the new federal housing system began, the number of Brazilian municipalities with municipal housing increased from 14\% in 2004 to $76 \%$ in 2011, according to Instituto Brasileiro de Geografia e Estatística (IBGE). ${ }^{18}$

As part of Brazil's programme for the Acceleration of Growth (PAC), the Brazilian government launched PMCMV in 2009. The programme is funded by a federal budget and it is now in its third phase (PAC 3), which has included investment of up to R\$210.6 billion over a three-year period. Before the implementation of this programme, mortgages were not available for low-income families, which were left entirely in the hands of the private sector, with only small and targeted investment housing. Consequently, it is no surprise that favelas and other informal dwellings became legitimate mass housing in Brazil, considering the working-class freedom to build and to increment housing spaces outside the normative planning. ${ }^{19}$

The PMCMV programme is currently the main social housing programme, and according to official figures it has the capacity to deliver over four million houses. ${ }^{20}$ At face value, the programme has achieved success, but low-income groups (families earning 0-3 times the monthly minimum wage) have been the group to benefit the least from this programme.

Despite its national comprehensiveness, the programme has been subject to heavy criticism for its housing quality standards. Many buyers complain about the material utilised in construction, and also about the location of the houses. This is not very different from complaints during the self-construction housing programmes back in the 1980s and 1990s. Although monthly instalments are low, many buyers are in arrears and may face eviction. $^{21}$ 
Unfortunately, housing construction under the scheme has been slow-paced, especially considering that only $15 \%$ of the contracts are directed at low-income families. The remaining contracts assist families with income between 4 and 10 times the monthly minimum wage, where demand is smaller but repayment potential is higher. Even if the PMCMV was envisaged as a low-cost housing programme, the majority of the building companies are not able to take the risk of making only a marginal profit from it, especially when the possibility of compromising on quality standards is at stake, and they need to abide by building regulations. $^{22}$

The PMCMV has achieved great impact on the housing market in Brazil and it has the potential to reduce the housing deficit. The main concern is that the programme is repeating the same mistakes committed in the past: poor solutions for poor people. Higher income families are still the beneficiaries in the scheme and those from low-income groups complain about low-quality houses. The housing deficit in Brazil is concentrated on low-income groups, but without a social housing programme fully directed to them the housing deficit will not be properly solved. For that reason, social movements fighting for the right to housing have demanded their inclusion in the elaboration and implementation of social housing policies. This inclusion, however, has been compromised by the Workers' Party administration's distant relationship with its supporters' base. This situation is further aggravated by the economic crisis that has been affecting the country since 2014 .

In the next section, I analyse the role of the private sector in housing policies, with particular attention to its power and influence on social housing policymaking.

\section{Social housing production and the private sector}

Starting in the 1980s, national economic systems started to be disarticulated and, consequently, the autonomy of the state was affected, especially in terms of control of social and economic policies. ${ }^{23}$ This was a phenomenon observed in Latin American countries which defined a new pattern of capital accumulation and redefined the role of the state. Housing policies were deeply affected, as state resources were cut and a process of reduction of the role of the state was taking place. These changes affected virtually all economic and social areas. Regarding housing policies, its fundamental premise is that the market is, par excellence, capable of guaranteeing an efficient housing production and delivery. Therefore, the state should improve the operating conditions of markets and gradually abandon direct public housing production. This discourse fitted perfectly with the austerity economic policies proposed by the multilateral organisations at a time when the periphery was facing adjustments in productive, financial, political-ideological and social fields. The Brazilian state than became a facilitator, via financial operations. ${ }^{24}$

Those reforms had the explicit aim of strength the financial system. ${ }^{25}$ Beginning in this period, the construction sector in Brazil became an important player in housing policies, especially in the Workers' Party political economic programme in 2003. Accordingly, the annual housing financing was raised by $31.09 \%$ between 2003 and 2008, at a particular moment where companies aggregated international investments and moved to housing production focused on low-income groups. ${ }^{26}$ Despite record economic growth in 2007 and 2008, the onset of the global financial crisis severely hit Brazil in September 2008, as international demand for Brazil's commodity-based exports dropped and external credit withered. The initial expectation was that Brazil could circumvent the crisis since some macroeconomic 
fundamentals were considered good at the time. ${ }^{27}$ With the onset of the crisis in 2008, many construction companies dreaded the reduction of capital flows to the economy, the decrease of credit supply, and the negative impact on consumer and investment spending. ${ }^{28}$ The solution for the increasing economic uncertainty of the period was centred in the housing sector, an economic strategy that attended to the interests of the private sector, banks and construction companies. Thus, the PMCMV was a solution created to attend to the demands of the construction sector and the interests of international capital, which had heavily invested in Brazilian companies.

The PMCMV was created as a countercyclical policy articulated with the PAC. This programme addressed two major demands at the same time: on one hand, from the point of view of housing needs, the programme would reduce the housing deficit, while on the other hand, it would satisfy the interests of the private sector. In terms of resource allocation, there is great incentive to real estate, construction companies and banks. The incentives are both direct (via funding to support construction costs and subsidise private businesses), and indirect through loans to individuals to guarantee the demand. In addition, the real estate industry also benefits from tax exemption. For example, states and municipalities are expected to give away public land to construction companies to reduce construction costs (ministerial ordinance no. 164, 12 April 2013). They also exempted from Contribuição Social sobre o Lucro Líquido (CSLL), Programa de Integração Social (PIS) / Programa de Formação do Patrimônio do Servidor Público (PASEP), Imposto de Renda de Pessoa Jurídica (IRPJ) and Contribuição para o Financiamento da Segurida (COFINS), among other taxes.

The PMCMV was evaluated by the private sector as the most suitable model to boost housing production, safeguarding a leading role in the industry. ${ }^{29}$ Considering this programme is strongly dependent on the private sector, it contradicts the main principles of the National Housing System, which indicate that funding for social housing should be concentrated on social housing provision. However, a great part of this funding was spent on housing projects already under way, and on complementary construction such as the urbanisation of settlements and infrastructure projects around those areas. Oliveira ${ }^{30}$ highlights how this practice countervails resolutions adopted by the National Housing Fund and reveals the influence of the private sector on housing developments. Rolnik and Nakano have criticised this model by stating that merely implementing efficient job creation policies and boosting the construction sector do not necessarily result in a good housing policy. ${ }^{31}$

Also, research shows the confluence of the Workers' Party's and the private sector's interests in at least three different aspects of social housing policy: (1) the first term of the Workers' Party administration developed a regulatory framework for the real estate market, promoting housing investments; (2) the elaboration of an infrastructure investment agenda in the second term resulted in a partnership programme that incorporated the private sector (construction companies in particular) as one of the main agents of economic growth; and (3) a comprehensive social housing programme was developed, a long-standing demand of the private sector and housing movements. ${ }^{32} \mathrm{~A}$ combination of the above turned the private sector into the main protagonist of economic growth policies, and research shows that the great autonomy of the private sector increases the pressure to lift credit limits. This can, in turn, distort the social purposes of social housing programmes.

As an important partner of the government in housing policies, legislation requires the private sector to be present in municipal housing councils and dynamically participate in its activities. Their presence in housing councils is key for social movements, which could then 
speak directly to the companies interested in submitting housing projects. They could address communities' housing needs and take into consideration their claims. But despite having a representation on the national housing council and in municipal councils, the private sector is a largely absent player at the local level, and I show evidence of this in the next section.

\section{Private-sector intervention in social housing, the PMCMV programme and a municipal housing council}

A major demand from housing movements is for the provision of affordable housing to low-income groups. However, the influence of the private sector pushes for housing policies directed to the middle-upper classes - mainly because of their repayment capacity. ${ }^{33}$ In this context, social movements for housing are competing against two strong political forces. The first is the powerful and influential private sector, which has the power to delineate housing production; the second is the state, which is politically and economically aligned with the private sector.

The political force of the private sector in the area of housing dates from the first big social housing projects in the 1950s and 1960s, but it has developed new characteristics since the 1980 s and specially in the 2000s with the implementation of participatory democracy, the creation of the national housing system and the opening of housing councils. Its influence has also been expanded by the inclusion of business representatives in the political sphere, such as their inclusion in national councils and the creation in 2005 of the National Industrial Development Council (Conselho Nacional de Desenvolvimento Industrial), which was officially the channel of negotiation between the government and business sectors. It was created to assure the private sector that a left-wing government was not going to be a 'disaster', as the sector was apprehensive about Lula's government, which according to some would adopt a more radical political attitude. ${ }^{34}$

A look at the history of state intervention on housing shows that the role of the state in providing housing - a constitutional right - has been transferred to the market. Research on the topic has consistently demonstrated that, over the years, the state relocated a significant portion of the decision-making power on housing issues to the private market. ${ }^{35}$ This model has privileged the construction companies in the main, with the guarantee of maximum return to investors and banks, as most of the current housing policies in Brazil are centred on the medium-high-income groups.

\section{PMCMV and the private sector}

An important but absent set of players in the Maracanaú housing council - the municipality where I conducted fieldwork - are private sector representatives. They are members of the council but are not elected like other council members representing social movements. According to the social housing legislation, the participation of the private sector is required because they are considered 'strategic partners of social housing policies. ${ }^{36}$ However, the municipal housing council rules of procedure do not determine a number of seats for representatives of the private sector. From attendance lists I observed that in each term there was at least one representative from the national bank and one from building companies. I also observed that in 2013-2014, building companies were not on the list of council members - apparently for lack of interest. 
The private sector has a role in issues regarding social housing policy, but I have found that they do not actively participate in the housing council. The reason for this is that they have different access points and consequently better access to senior officials. They prefer to deal only with them, as council members have stated in interviews. In practice, they do not have a direct involvement in the council; rather, they use government officials as representatives of their interests in housing policies. Document analysis of attendance lists showed representatives of the private sector did not attend meetings in 2013; and in previous years, they rarely attended meetings.

A possible explanation for the lack of participation of representatives of the private sector in council meetings is to avoid dealing with communities' demands. As explained in previous sections, the private sector became the main protagonist of housing policies, and new housing projects depend on their capability and interest in proposing new housing developments. In council meetings, they will be challenged and pressured, so they prefer to deal with public officials only, thus using government officials as their representatives in the housing council. It would make sense for them to attend council meetings, so that they may push items of their interest onto the council's agenda, but their close connections to government representatives saves them the trouble of attending. In other words, they do not attend meetings because they do not need to.

The above was confirmed when I looked at the way information on new housing developments is presented at the housing council. Public officials are in charge of presenting the projects and council members are expected to approve new projects. Demands coming from council representatives are not necessarily embedded in proposals coming from the private companies, but a middle ground needs to be reached; otherwise, new housing projects will not be approved. New social housing projects should consider human needs, but in practice they take into account market interests. In this context, social housing has to be profitable for the private sector too. To compensate the lack of participation of developers, public officials sustain and defend projects proposed by the private sector during council meetings. This distorted logic puts into question the capability of social movements' representatives in the housing council to influence the outcomes of housing policies.

The private sector's facilitated access to public officials illustrates the different ways of participation in the housing council. For them, access to a government official is informally facilitated. The reality for Social Movement Organisation (SMO) members is quite different: they are constantly struggling for access to information.

This distortion of housing priorities clashes directly with the demands of the popular sectors and also exposes the incompatibility of purpose of social housing policies with the business model of housing production. Reconciliation seems unlikely, as the interests of entrepreneurs have a significant influence on (and, to some extent, determine) public investment in housing. The public towards which these policies are supposed to be directed do not benefit from it properly, to the detriment of the social function of housing policy. ${ }^{37}$

Donaghy investigated the relationship between the private sector and government in a city in São Paulo. She found that the close connections between the private sector and the local government privilege the interests of the private sector. ${ }^{38}$ She confirmed this by observing how the two generally agree on issues and form a strong voting bloc in the municipal council. She also found that the private sector has always favoured large-scale projects rather than the ones that would satisfy demands for affordable housing to the poor. In this particular council in São Paulo, representatives of the private sector take the time to attend the council 
meetings because social movements and other entities from civil society present a permanent challenge to government/private sector plans. In terms of the council I am studying, there is less resistance and representatives do not feel the need to attend meetings, as government representatives have been able to influence housing policies in such a way as to benefit private business. Another important finding was that, differently from councils in Donaghy's case study, social movement representatives were not able to form a strong voting bloc to pressure government and builders to attend their housing demands.

Also relevant to the issue of private sector involvement with social housing is the Minha Casa Minha Vida - Entidades (MCMV-E). It was created five months after the launch of the PMCMV, as a result of the pressure from social movements. Compared to the main programme, MCMV-E is a much smaller umbrella programme in which only families with monthly income up to 3 times the monthly minimum wage can be attended. The MCMV-E represents only $3 \%$ of the total PMCMV projects and consists of allocation of public resources to social housing that are managed by civil society entities. ${ }^{39}$

The MCMV-E has been acclaimed as a victory by housing movements. The backbone of MCMV-E lies in the idea of participation as a form of popular organisation. This participation happens on two levels: through direct transfer of federal resources to the implementation of housing projects, and the participation of the beneficiary families, selected and organised by the movements. ${ }^{40}$ This sub-programme recognised that social movements are also partners in implementing social housing policies, and not just the private sector. ${ }^{41}$ However, recent studies have pointed to the contradictions of the Workers' Party's housing policy where the self-managed model versus the private model are two conflicting models of housing production. While the private sector emphasises efficiency and large-scale housing projects, MCMV-E is focused on the idea of civil society capacity for self-management, connected to popular participation and accountability. ${ }^{42}$ The relationship between MCMV-E and the private sector is complex, but differently from what happens in local council, housing movements engaged with MCMV-E projects make decisions regarding implementation and construction. Compared to the PMCMV, entities involved with MCMV-E have assumed a leading role in the production of housing units.

Housing movements in this context of the housing council are competing for power and influence against two strong political actors. One actor is the private sector, which is seen as the main instrument for economic growth and is in the position of being able to create maximum leverage on housing policies, whilst social movements are competing against a strong network of interests composed of political elites and the business sector. The other actor is government, represented by political elites and public officials, who are expected to promote the strength of housing councils, but are not interested in keeping social movements and the private sector at the same discussion table, so they may end up listening to only one side.

The network created at the federal level and amplified at the local level intensifies the consequences of keeping the fundamental decision-making power in the hands of a sector that is not interested in promoting local councils. With a strong power imbalance in housing council, the way it operates may legitimise a housing policy that does not take into consideration local demands, but rather is one that might prioritise housing projects designed according to the interests of private companies.

Social movements are aware of this power imbalance. This has led to a sense of frustration experienced by social movements and especially by Workers' Party militants. In the next 
section, I discuss the reactions of social movements to this and the contractions of the social housing policy implemented by the Workers' Party.

\section{Decision power and popular participation}

The Workers' Party government forged a new relationship with the private sector, since its attempts to maintain power rely on economic growth and high levels of employment, which implies the creation of partnerships with the business sector. ${ }^{43}$ As an initially highly ideological political party that moved towards the centre and became a moderate left-wing government, the Workers' Party implemented a series of developmentalist and neoliberal policies. In order to take and retain power and political support, the Workers' Party had to continue to appeal to the masses and at the same time assure the economic elite that they would respect their interests as well. ${ }^{44}$ In practice, this means that the Brazilian growth model has been led by the economic elites in a post-neoliberal capitalist model that centres efforts on reducing extreme poverty (through cash transfer programmes and job creation) while promoting the agenda of industrial elites, considered by some to be essential for economic growth and development. This is done through maintaining an effective tax credit system that subsidises big business in the state. ${ }^{45}$

When elected in 2003, Lula publicly promised to keep social movements close to his administration by including them in the decision-making process. It was indeed implemented through the creation of local councils and the allocation of funding for them. However, despite having a seat in councils, in special municipal housing councils, social movements were not given real decision power, as the power lies in the hands of the private sector. In Rousseff's administration, this situation did not change much: social movements and civil society continue with no or little decision power, especially because Rousseff moved towards openly neoliberal policies. ${ }^{46}$

As the Workers' Party administration evolved, social movements continued to be excluded from the high spheres of decision-power. Although those groups have shown a willingness to take part in the process of formulating public policy, it is possible to observe the disconnection between the Workers' Party's 'architecture of participation' and the unequal level of influence the private sector has on decision-making. The creation and implementation of spaces of participation were not enough to overcome the traditional rent-seeking employed by Brazilian elites, and, as a consequence, many councils became spaces for dialogue and discussion, but not decision-making. Dagnino and Teixeira ${ }^{47}$ show, for example, that $58 \%$ of the national councils are consultative only and not deliberative (some councils are advisory only, meaning their decisions do not necessarily need to be taken into account; they exist in an advisory capacity).

It is possible to see some advances in the broadening of spaces of participation and discussion on matters that concern citizens. Nevertheless, the promotion of popular participation is not associated with tangible changes in the way those spaces function.

\section{Conclusion}

The Workers' Party trajectory is controversial because, despite some advances in the social domain, there has been no significant attempt to reform the political system or challenge the ideological hegemony of neoliberalism. Many Workers' Party supporters - and adversaries 
- criticise the pro-corporate development strategy implemented in the last 10 years. While supporters highlight the economic growth in the first three terms of the Workers' Party administration (which saw a reduction in extreme poverty and the implementation of models of democratic and participatory government), Lula and Rousseff's governments based their political power strategy on a partnership with big business on the one hand and the expansion of social policies for low-income groups on the other. This balance, too fragile to withstand the dispute over power and influence, shifted towards economic elites, who, as in the example of the private companies, are not interested in engaging in negotiations for decision-making power with citizens.

The changes in housing policymaking are important for two reasons. First, they reveal that a political party in power - one with a solid social programme and a growing economy - is capable of reducing inequality and poverty by promoting consistent social gains, which includes access to better quality social services and decent housing. Second, while social gains can be observed, those changes did not result in a wider sharing of wealth and power. The Workers' Party promoted in a decade a combination of poverty reduction and economic growth policies. However, the party was unable to maintain a sustainable growth - in part due to the global uncertainty of the markets - and it was unable to hold on to its electoral support base. As a consequence, the housing sector has also been affected, first by the strong intervention of the private sector in the process of decision-making, and, second, by the several economic and political crises that have affected Brazil since Rousseff's impeachment in May 2016.

In the context of the PMCMV, it is not the central or local governments that determine which type of housing development will be implemented. The role of municipalities became one of making information on housing demands available and to help to identify families who fit the scope of the programme. The state has also to facilitate housing production through tax relief and the relaxation of planning legislation. In summary, the main promoter of social housing is no longer the government sector but the private sector.

Furthermore, the economic crisis that started in 2014 and the severe political crisis in 2016 only add to increasing uncertainty about investments in social housing policies and the application of resources in the sector. For now, it is possible to observe the return of neoliberal public policies, with cuts in social spending and attempts to privatise key social services.

\section{Disclosure statement}

No potential conflict of interest was reported by the author.

\section{Funding}

The Irish Research Council under the Government of Ireland Research Scheme Grant supported this work.

\section{Note on Contributor}

Valesca Lima is a Postdoctoral researcher at University College Dublin, Ireland. Her work focuses on housing policies and governance. 


\section{Notes}

1. Valença, Poor Politics - Poor Housing, 391; Valença, Moraes, and Fialho Bonates, "Trajectory of Social Housing Policy"; Bonduki, "Origens da Habitaçao Social," 711; Bonduki, "Housing Policies and Politics," 70; Bonduki, "Urban and Housing Policy," 176; Rolnik, A cidade e a lei, 101-44; and Cardoso, Programa Minha Casa Minha Vida, 7.

2. Maricato, Brasil, Cidades; Azevedo and Andrade, Habitação e poder, Azevedo, "Política de Habitação Popular"; Cardoso and Aragão, "Programa Minha Casa Minha Vida," 17.

3. IBGE, Pesquisa de Informacoes Basicas Municipais.

4. Dagnino and Teixeira, "Participation of Civil Society"; Teixeira, Os Sentidos da Democracia; Teixeira, De Souza, and Pompeu Fiuza Lima, Arquitetura da participação no Brasil.

5. Cardoso and Aragão, "Programa Minha Casa Minha Vida”; and Krause, Balbim, and Correia Lima Neto, Onde fica política habitacional.

6. Donaghy, Civil Society and Participatory Governance; and Coelho, "Brazil's Health Councils."

7. Stedile, Boff, and Chaui, Leituras da Crise.

8. Morais and Saad-Filho, "Neo-Developmentalism and the Challenges"; Petras, Brasil e Lula: Ano Zero; Antunes, "Trade Unions, Social Conflict"; and Sánchez, Borges Neto, and Marques, "Brazil. Lula's Government."

9. Dauvergne and Farias, "Rise of Brazil."

10. Bonduki, "Housing Policies and Politics"; and Bonduki, "Urban and Housing Policies."

11. Bonduki, "Origens da Habitacao Social," 711.

12. Bonduki and Koury, Os Pioneiros Da Habitação, 18-40.

13. Bonduki, "Origens da Habitacao Social," 724.

14. Bonduki, "Housing Policies and Politics."

15. McGregor et al., "Do Elections Matter," 3.

16. Mioto, "Política Habitacional na América Latina," p. 185.

17. Cardoso et al., Da Euforia a Crise, 19.

18. IBGE, Pesquisa de Informacoes Basicas Municipais.

19. Cavalcanti, "Normative, Institutional Social Housing System," 5 .

20. Cardoso, "Da Euforia a Crise," 19.

21. Bonduki, "Urban and Housing Policy."

22. Cardoso and Aragão, "O Programa Minha Casa Minha Vida E Seus Efeitos."

23. Furtado, Brasil: a construção interrompida, 32.

24. Mioto, "Política Habitacional na América Latina," 187-8.

25. Mendonça, "Prudential Regulation and Safety Net," 189.

26. Mioto, "Política Habitacional na América Latina," 189.

27. Paula and Sobreira, "The 2008 Financial Crisis," 77.

28. Ibid., 91.

29. Oliveira, J., "Política Social e Política Econômica," 331-2.

30. Ibid., 332.

31. Rolnik and Nakano, "Trap of Housing Packages," 3-4.

32. Arretche et al., Capacidades Administrativas Dos Municípios.

33. Bonduki, "Housing Policies and Politics"; and Jesus, A Política Pública Habitacional.

34. Diniz, Difícil Rota Do Desenvolvimento, 80.

35. Bonduki, "Housing Policies and Politics"; Ribeiro and Azevedo, A Crise Da Moradia; Oliveira, "Política Social e Política Econômica," 333-5.

36. National Housing Plan, 2009 (based on Law 11.124/2005).

37. Motta, A Questão Da Habitação No Brasil.

38. Donaghy, Civil Society and Participatory Governance, 157.

39. Tatagiba et al., Inovacoes Participativas nas Politicas Habitacionais, 6-9.

40. Ibid., 7.

41. Ibid., 8.

42. Viana, Programa Minha Casa Minha Vida, 56.

43. Dias, "Rearticulação Da Política Habitacional." 
44. Vanden, "Taking the Streets, Swarming Public Spaces," 242.

45. Bresser-Pereira, "Empresários, O Governo do PT"; and Baiocchi, “Emergent Public Spheres."

46. Morais and Saad-Filho, "Neo-Developmentalism and the Challenges."

47. Dagnino and Teixeira, "Participation of Civil Society," 52-3.

\section{Bibliography}

Antunes, Ricardo. "Trade Unions, Social Conflict, and the Political Left in Present-Day Brazil." In The New Latin American Left: Cracks in the Empire, edited by Jeffery R. Webber and Barry Carr, 255-276. Rowman \& Littlefield, 2012.

Arretche, Marta T. S., Berenice de Souza Cordeiro, Edgard Fusaro, Edney Cielici Dias, and Mariana Bittar. Capacidades Administrativas Dos Municípios Brasileiros Para a Política Habitacional [Housing Policy Administrative Capacities of Brazilian Municipalities]. São Paulo: Universidade de São Paulo, 2012.

Azevedo, Sergio de. "Vinte e dois anos de política de habitação popular (1964-86): criação, trajetória e extinção do BNH." [Twenty-Two Years of Social Housing Policy (1964-86): Creation, Trajectory and Extinction of BNH.] Revista de Administração Pública 22, no. 4 (10 July 1988): 107-119.

Azevedo, Sérgio de, and Luís Aureliano Gama de Andrade. Habitação E Poder: Da Fundação Da Casa Popular Ao Banco Nacional Habitação [Housing and Power: From the Popular House Foundation to the National Housing Bank]. Rio de Janeiro: Centro Edelstein, 2011.

Baiocchi, Gianpaolo. “Emergent Public Spheres: Talking Politics in Participatory Governance." American Sociological Review 68, no. 1 (2003): 52-74.

Bonduki, Nabil. "Origens Da Habitação Social No Brasil." [Origins of Social Housing in Brazil.] Revista Análise Social 127, no. 3 (1994): 711-732.

Bonduki, Nabil. "Housing Policies and Politics and Social Inclusion in Brazil: An Orverview of New Perspectives in Lula's Government [Política Habitacional E Inclusão Social No Brasil: Revisão Histórica E Novas Perspectivas No Governo Lula]." Revista Eletrônica de Arquitetura E Urbanismo, 1 (2008): 70-104.

Bonduki, Nabil. "Urban and Housing Policy from Lula to Dilma: Social Inclusion with Territorial Segregation." In Brazil Under the Workers' Party, edited by Fábio de Castro, Kees Koonings, and Marianne Wiesebron, 176-198. London: Palgrave Macmillan, 2014.

Bonduki, Nabil, and Ana Paula Koury. Os Pioneiros Da Habitação Social No Brasil [The Pioneers of Social Housing in Brazil]. Vol. 1. Sao Paulo: Fapesp, 2014.

Bresser-Pereira, Luiz Carlos. “Empresários, O Governo Do PT E O Desenvolvimentismo [Entrepreneurs, the PT Government and Developmentalism]." Revista de Sociologia E Política 21, no. 47 (September 2013): 21-29.

Cardoso, Adauto Lucio. O Programa Minha Casa Minha Vida e Seus Efeitos Territoriais [The Programa Minha Casa Minha Vida and Its Territorial Effects Program]. Rio de Janeiro: Letra Capital Editora, 2013.

Cardoso, Adauto Lucio, and T. Amorin Aragão. "O Programa Minha Casa Minha Vida E Seus Efeitos Territoriais [The Programa Minha Casa Minha Vida and Its Territorial Effects Program]." In Do Fim Do BNH Ao Programa Minha Casa Minha Vida: 25 Anos Da Política Habitacional No Brasil, edited by Adauto Lucio Cardoso, 17-66. Rio de Janeiro: Letra Capital, 2013.

Cardoso, Adauto Lucio, Thêmis Amorim Aragão, and Samuel Thomas Jaenisch. Vinte e dois anos de política habitacional no Brasil: da euforia à crise, 15. Rio de Janeiro: Letra Capital, 2017.

Cavalcanti, Ana Rosa Chagas. “Favelas and the Normative, Institutional Social Housing System in Brazil: Discipline versus Freedom, Private versus Public through the Analysis of the Unprivileged WorkingClass History." In International Planning History Society Proceedings 17, no. 4 (2016).

Coelho, Vera Schattan P. "Brazil's Health Councils: The Challenge of Building Participatory Political Institutions." IDS Bulletin 35, no. 2 (April 1, 2004): 33-39.

Dagnino, Evelina, and Ana Claudia Teixeira. "The Participation of Civil Society in Lula's Government. Journal of Politics in Latin America 6 (2014): 39-66.

Dauvergne, Peter, and Déborah B. L. Farias. "The Rise of Brazil as a Global Development Power." Third World Quarterly 33, no. 5 (2012): 903-917.

Dias, Edney Cielici. "Trajetória e agendas na rearticulação da política habitacional brasileira: o governo federal e os empresários da construção (1994-2010) [Trajectory and Agendas in the Articulation of 
the Brazilian Housing Policy:The Federal Government and the Construction Sector Entrepreneurs]." Seminar presented at the II Seminário Discente da Pós-Graduação em Ciência Política da Universidade de São Paulo, Sao Paulo, 2012.

Diniz, Eli. A difícil rota do desenvolvimento:empresários e a agenda pós-neoliberal [The Difficult Route of Development: Entrepreneurs and the Post-Neoliberal Agenda]. Belo Horizonte: Editora UFMG, 2007.

Donaghy, Maureen M. Civil Society and Participatory Governance: Municipal Councils and Social Housing Programs in Brazil. Vol. 5. New York: Routledge, 2013.

Furtado, Celso. Brasil: a Construcao Interrompida [Brazil: The Interrupted Construction]. Sao Paulo: Paz e Terra, 1992.

IBGE (Instituto Brasileiro de Geografia e Estatística). Pesquisa de Informacoes Basicas Municipais: Perfil Dos Municipios Brasileiros, Gestao Publica (MUNIC) 2012 [Basic Municipal Information: Brazilian Municipalities Profile]. Brazil: IBGE, 2012.

Jesus, Sara Livino de. A Política Pública Habitacional e os Desdobramentos do Programa Minha Casa Minha Vida em Uma Cidade Média: Dourados-Ms [Public Housing Policy and the Development of the Programa Minha Casa Minha Vida in a Average-size City: Dourados-Ms]. Universidade Federal da Grande Dourados, 2014. http://tede.ufgd.edu.br/jspui/handle/tede/384

Krause, Cleandro, Renato Balbim, and Vicente Correia Lima Neto. Minha Casa Minha Vida, Nosso Crescimento: Onde Fica Política Habitacional? Texto Para Discussão [Minha Casa Minha Vida, My Home My Life, Our Growth: Where is Housing Policy?]. Brasilia: IPEA, 2013.

Maricato, Erminia. Brasil, Cidades: Alternativas Para A Crise Urbana [Brazil, Cities: Alternatives to the Urban Crisis]. São Paulo: Vozes, 2001.

McGregor, Alecia J., Carlos Eduardo Siqueira, Alan M. Zaslavsky, and Robert J. Blendon. "Do Elections Matter for Private-Sector Healthcare Management in Brazil? An Analysis of Municipal Health Policy." BMC Health Services Research 17 (12 July 2017): 483-495.

Mendonça, Ana Rosa Ribeiro de. "Prudential Regulation And Safety Net: Recent Transformations In Brazil." In Capital Without Borders: Challenges to Development, edited by Ashwini Deshpande (Org.), 187-205. India: Anthem Press, 2011.

Ministério das Cidades. National Housing System. Brasil: Ministério das Cidades, 2009.

Mioto, Beatriz Tamaso. “A Política Habitacional na América Latina no século XXI: uma análise comparativa entre o caso brasileiro e venezuelano [The Housing Policy in Latin America in the 21st Century: A Comparative Analysis Between the Brazilian and Venezuelan's Cases]." In 22 anos de política habitacional no Brasil: da euforia à crise, edited by Adauto Lucio Cardoso, Thêmis Amorim Aragão, and Samuel Thomas Jaenisch, 178-208. Letra Capital Editora LTDA, 2017.

Morais, Lecio, and Alfredo Saad-Filho. "Neo-Developmentalism and the Challenges of Economic PolicyMaking under Dilma Rousseff." Critical Sociology 38, no. 6 (1 November 2012): 789-798.

Motta, Luana. A Questão Da Habitação No Brasil: Políticas Públicas [The Housing Issue in Brazil: Public Policies]. Gesta - UFMG: Conflitos Urbanos E O Direito À Cidade. 2010. http://conflitosambientaismg. Icc.ufmg.br/wp-content/uploads/2014/04/TAMC-MOTTA_Luana_-_A_questao_da_habitacao_no_ Brasil.pdf.

Oliveira, Julio. “As Dimensões Corporativas Do Programa Minha Casa, Minha Vida, O Dilema Do Limite Entre Política Social E Política Econômica." In 22 Anos de Política Habitacional No Brasil: Da Euforia À Crise. 1st ed. Rio de Janeiro: Letra Capital, 2017.

Paula, Luiz Fernando de, and Rogério Sobreira. "The 2008 Financial Crisis and Banking Regulation in Brazil." In An Assessment of the Global Impact of the Financial Crisis, edited by Phillip Arestis, Rogério Sobreira, and José Luis Oreiro, 209-235. London: Palgrave Macmillan, 2011.

Petras, James. Brasil E Lula: Ano Zero [Brazil and Lula: Year Zero]. Blumenau, Brazil: Edifurb, 2005.

Ribeiro, Luiz Cesar de Queiroz, and Sérgio de Azevedo, eds. A Crise Da Moradia Nas Grandes Cidades: Da Questão Da Habitação À Reforma Urbana [The Housing Crisis in Large Cities: From Housing to Urban Reform]. Editora UFRJ. Rio de Janeiro: UFRJ, 1996.

Rolnik, Raquel. A Cidade E a Lei: Legislação, Política Urbana E Territórios Na Cidade De São Paulo [The City and the Law: Legislation, Urban Policies and Territories in the City of São Paulo]. São Paulo: Studio Nobel, 1997. 
Rolnik, Raquel, and Kazui Nakano. "The Trap of Housing Packages [As Armadilhas Do Pacote Habitacional]." Le Monde - Diplomatique Brazil. 2009. On-line edition edition. http://diplomatique. uol.com.br/artigo.php?id=461\&PHPSESSID=726ce1 cea7ec25bc237a5943

Sánchez, Félix, João Machado Borges Neto, and Rosa Maria Marques. "Brazil. Lula's Government: A Critical Appraisal." In The New Latin American Left: Utopia Reborn, edited by Patrick Barrett, Daniel Chavez, and César Rodríguez-Garavito, 42-68. London: Pluto Press, 2008.

Stedile, Joao Pedro, Leonardo Boff, and Marilena Chaui. Leituras Da Crise: Diálogos Sobre O PT, a Democracia Brasileira EO Socialismo [Crisis Understanding: Discussion on the PT, Brazilian Democracy and Socialism]. São Paulo: Fundação Perseu Abramo, 2006.

Tatagiba, Luciana, Ana Claudia Teixeira, Karin Blikstad, and Stella Zagatto Paterniani. Inovações Participativas Nas Políticas Habitacionais Para População de Baixa Renda: Um Estudo de Caso Sobre O Programa Minha Casa, Minha Vida - Entidades [Participatory Innovations in Housing Policies for Low Income Population: A Case Study on the Programa Minha Casa, Minha Vida - Entidades]. Relatórió Final de Pesquisa. Unicamp. Sao Paulo: CLACSO-ASDI, 2013.

Teixeira, Ana Claudia. Os Sentidos Da Democracia E Da Participação. Rio de Janeiro: POLIS Institute, 2005. Teixeira, Ana Claudia Chaves, Clóvis Henrique Leite De Souza, and Paula Pompeu Fiuza Lima. Arquitetura da participação no Brasil: Uma leitura das representações políticas em espaços participativos nacionais. Texto para Discussão, Instituto de Pesquisa Econômica Aplicada (IPEA), 2012. http://www.econstor. eu/jspui/handle/10419/91430

Valença, Márcio Moraes. "Poor Politics - Poor Housing. Policy under the Collor Government in Brazil (1990-92)." Environment and Urbanization 19, no. 2 (1 October 2007): 391-408.

Valença, Márcio Moraes, and Mariana Fialho Bonates. "The Trajectory of Social Housing Policy in Brazil: From the National Housing Bank to the Ministry of the Cities." Habitat International 34, no. 2 (April 2010): 165-173.

Vanden, Harry E. “Taking the Streets, Swarming Public Spaces:The 2013 Popular Protests." In Rethinking Latin American Social Movements - Radical Action from Below, edited by Richard Stahler-Sholk, Harry E. Vanden, and Marc Becker, 233-249. Latin American Perspectives in the Classroom, 2013.

Viana, Rafael Rocha. Programa Minha Casa Minha Vida - Entidades : A Look at the Actors' Actions around Controversies. Brasília: Universidade de Brasília, 2017. 